\title{
Diffuse Mesothelioma and Exposure to Asbestos Dust in the Merseyside Area
}

\author{
W. GLYN OWEN,* M.B., B.S.
}

[With Special Plate]

Brit. med. F., 1964, 2, 214-218

Paticnts suffering from pulmonary asbestosis show a high incidence of malignant-tumour formation. Particular attention has been given in the past to the occurrence of carcinoma of the lung. Doll (1955) assessed the average risk among men employed for 20 or more years at one asbestos factory as 10 times that among the general population. More recently a close association has been found to exist between exposure to asbestos and the development of diffuse mesothelioma. Wagner et al. (1960) described 33 examples of diffuse pleural mesothelioma from the North Western Cape Province of South Africa. All but one of the patients had been exposed to asbestos and many had worked in the local asbestos mines. Later, Wagner (1962) described 75 cases of diffuse pleural mesothelioma together with three examples of diffuse peritoneal mesothelioma. Occupational or environmental exposure to asbestos had occurred in all but two of the patients. In the present investigation a study has been made of 17 examples of diffuse mesothelioma occurring in the Merseyside area. In each case evidence has been sought of exposure to asbestos dust.

\section{Subjects and Methods}

The series includes 16 examples of diffuse pleural mesothelioma and one example of diffuse peritoneal mesothelioma. Most of the names were collected from the files of the Liverpool Cancer Control Organization and from those of the Liverpool Regional Thoracic Surgery Unit, which is based at this hospital. They cover a period of eight years from 1955 to 1963 .

A critical examination was made of all available histological material, and in only one instance was the diagnosis of diffuse mesothelioma accepted without histological reassessment. In this case necropsy had been performed in 1958, but none of the blocks or sections could be found. Tumour tissue was obtained at thoracotomy alone in six patients, at necropsy alone in eight patients, and from both these sources in three patients. The reports of 12 post-mortem examinations were available.

Evidence of exposure to asbestos was sought by taking careful occupational histories from the patients themselves or from their next of kin. In addition, lung tissue was examined microscopically for the presence of asbestos bodies wherever it was possible to do so. No attempt was made to obtain information from factories or other industrial concerns where the patients had been employed.

\section{Results}

Strong positive evidence of exposure to asbestos was obtained in $14(82 \%)$ of the 17 cases studied. Each of the other three patients had been employed in places where they may have handled asbestos, but there is no detailed information about the nature of their duties.

\section{Occupation of the Patients}

Eleven patients are known to have handled asbestos during the course of their work. Another held clerical appointments only, but had worked in the office of a factory where the atmosphere is frequently contaminated by asbestos dust. Five patients gave a negative or inconclusive occupational history, but in two of them asbestos bodies were seen in sections of lung tissue.

Of those giving a clear history of exposure seven were concerned with fire-proofing or heat-insulation. Five of these were laggers employed by firms of insulation engineers and were mainly engaged in the lagging of steam-pipes. Two were sheetmetal workers and boiler-makers. Both of these and three of the laggers had worked in ship-repairers' yards. Only two patients had worked in factories directly concerned with the processing of asbestos-one as a card-room operative for a period of five years from 1914 to 1919 , and the other as foreman for most of his working life. Two female patients had spent many years as sorters of used sacking, being employed by different firms of sackware manufacturers. Old sacks submitted for repair contained traces of their previous contents and usually were extremely dusty. In each of the factories asbestos sacks were notorious for the fine dust which they produced on handling.

The occupations of all the patients are listed in Table $I$. In every case the first known exposure to asbestos had occurred many years before the development of a tumour. The shortest interval was 13 and the longest 66 years, with an average of 38.5. Length of exposure ranged from 5 to 55 years, and the interval between the end of exposure and the development of tumour from a few months to 40 years.

\section{LEGENDS TO SPECIAL PLATE}

\section{W. GLYN OWEN}

Fig. 1.-Case 5. Tumour-lined clefts within a fibrous stroma. $(\mathrm{H}$. and $\mathrm{E} . \quad \times 80$.) Fig. 2.-Case 3. An area of papillary tumour formation. (H.

Fig. 3.-Case 9. High-power view of an area of papillary tumour. (H. and E. $\times 315$.)

FIG. 4.-Case 3. A single asbestos body lying within an alveolar septum. (H. and E. $\times 315$.)

FIG. 5.-Case 6. A group of asbestos bodies in lung tissue. (H. and E. $\times 315$.)

\section{E. DENT and L. C. A. WATSON}

FIG. 1.-Phalangeal $x$-ray films (a) on 14 August 1962 and (b) on 6 November 1963. Minimal subperiosteal erosion is visible on the left margin of the middle phalanx, and there is a double line at the terminal tuft indicating further erosion there. Both changes have healed in the later $x$-ray film after parathyroidectomy. Fig. 2.-Phalangeal $x$-ray films (a) on 14 August 1962 and (b)
on 6 November 1963. There is a particularly well-marked on 6 November 1963. There is a particularty well-marked healed in the later $x$-ray film after the removal of the parathyroid tumour.

\footnotetext{
* Registrar in Pathology, Broadgreen Hospital, Liverpool.
} 
W. GLYN OWEN: DIFFUSE MESOTHELIOMA

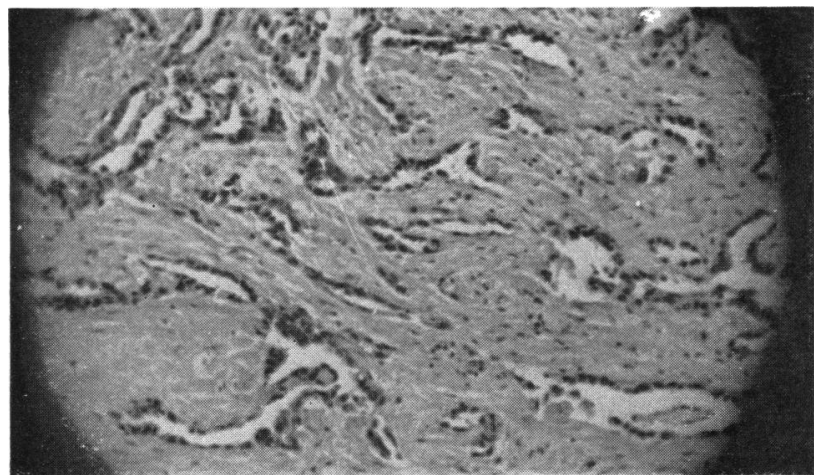

FIg. 1
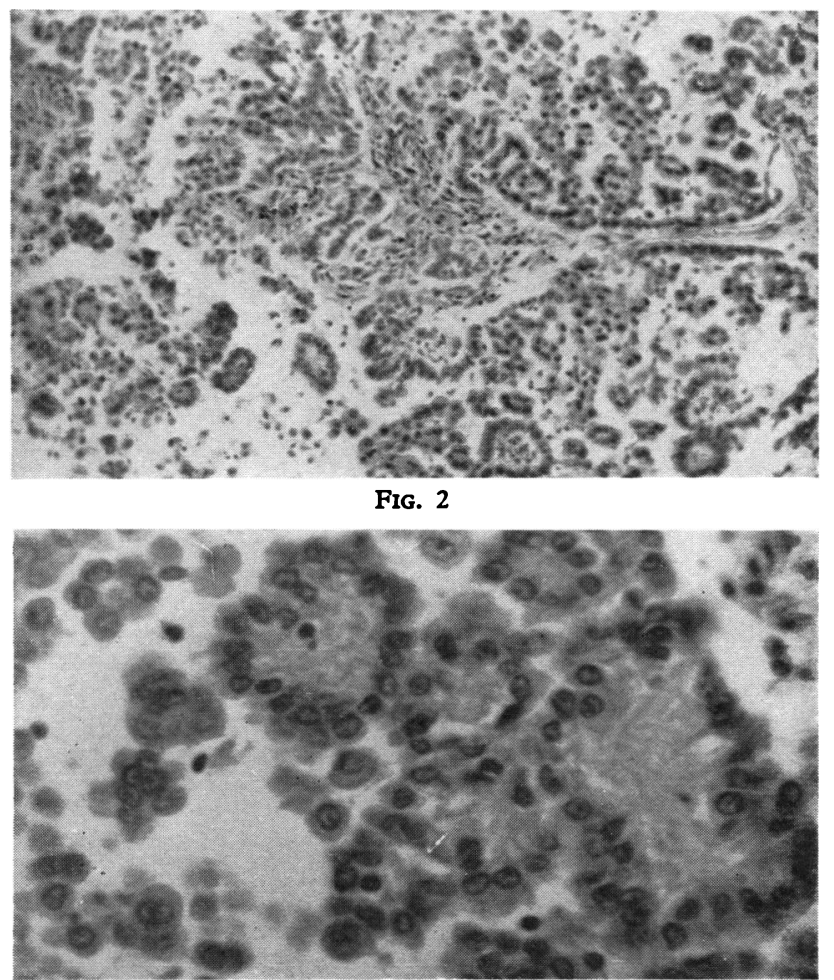

FIG. 3

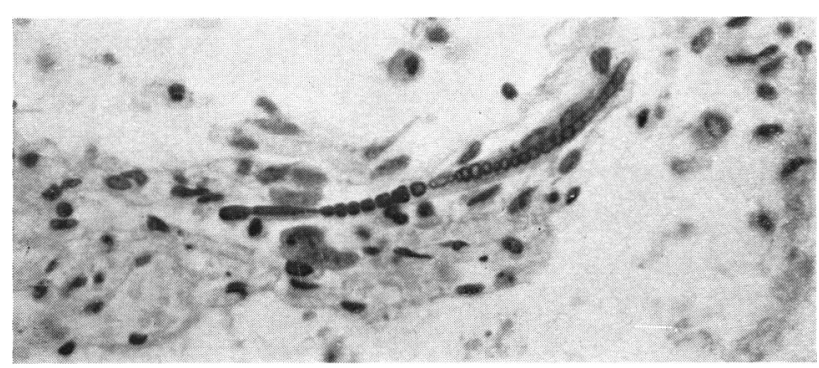

FIG. 4

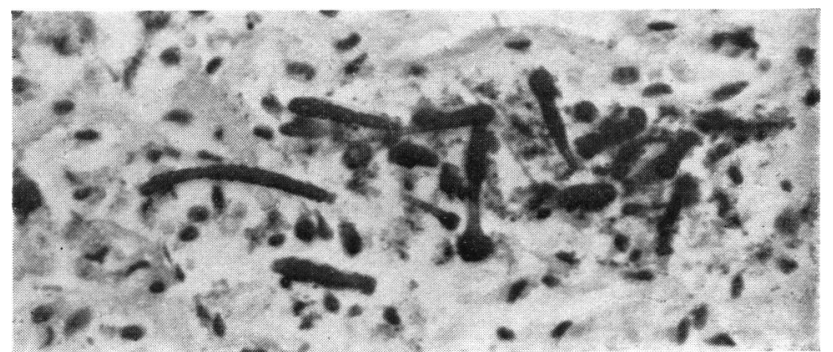

FIG. 5
C. E. DENT AND L. WATSON: HYPERPARATHYROIDISM AND CANCER
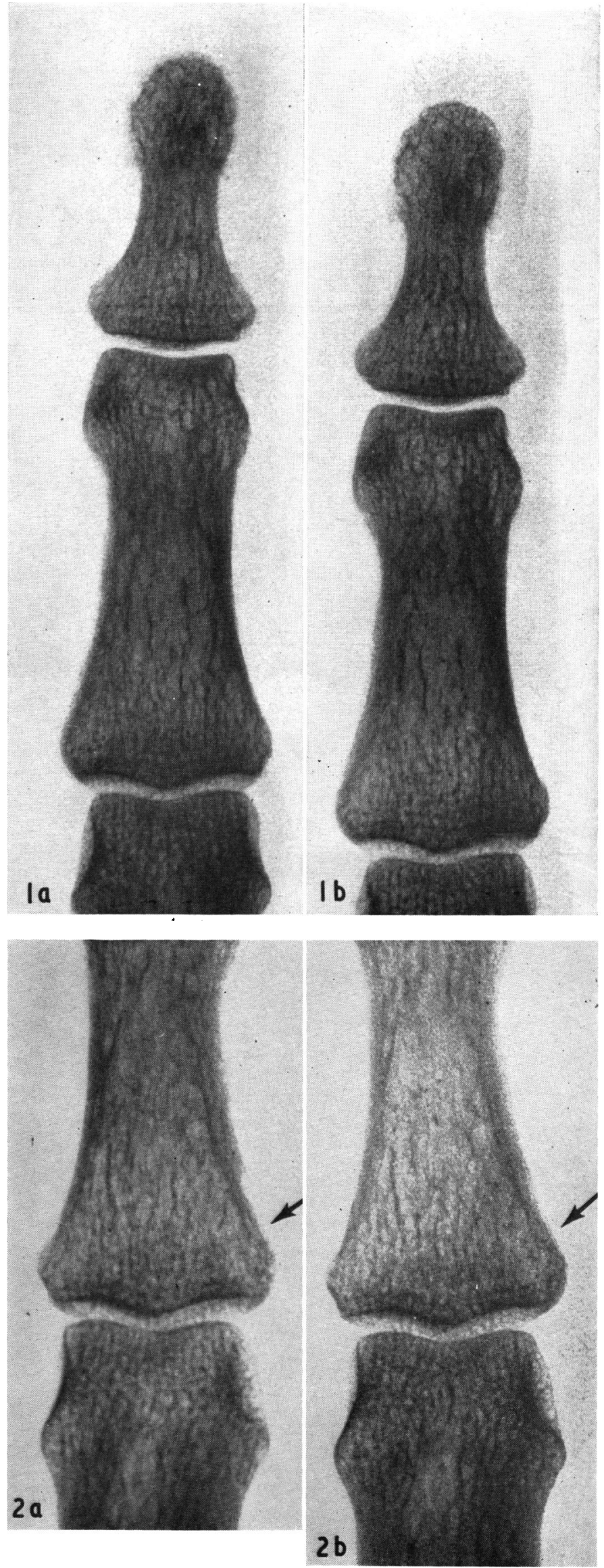


\section{Clinical Features}

A striking similarity is apparent in the presenting symptoms and in the course of the illness in all patients. Of those with primary growths in the pleura all complained of breathlessness and all but one of pain in the chest. Pain, felt deeply in the chest wall, was more often of dull aching character than of pleuritic type and was frequently accompanied by pain in the shoulder. Once established, both pain and breathlessness were distressingly persistent, becoming more severe with advance of the disease. Cough was not a prominent feature except where secondary respiratory infection had occurred. Eleven patients had pleural effusions when first examined in hospital and four developed effusions later. Numerous aspirations were carried out, but reaccumulation of fluid occurred with increasing rapidity until such time as tumour tissue had grown to obliterate the pleural space. Loss of weight was invariable but was often delayed until the final months of the illness.

Diagnosis remained in doubt in every case until exploratory thoracotomy or post-mortem examination was carried out. Bronchoscopy had been performed on 12 patients. Three showed rigidity of the bronchial tree and one showed compression of the left main bronchus. No bronchial tumour was seen and no other abnormalities were recorded.

The age and sex of all patients and the duration of their illnesses are given in Table I, together with details of their occupational histories. There were 12 male and five female patients. Only one is still alive. The average age was 58 years, the youngest patient being 46 and the oldest 82 at death. Rapid deterioration followed the onset of symptoms in eight cases. In the remainder the duration of symptoms ranged from one to six years, and four patients suffered protracted illnesses of over two years' duration. None of the patients complained of symptoms suggestive of pulmonary asbestosis. All had been in good health until the onset of symptoms attributable to the growth of tumour.

\section{Post-mortem Appearances}

Post-mortem examinations were carried out on 12 subjects. The main findings are summarized in Table II. In all cases extensive malignant growth was present, confined to the lining layers of serous cavities. One example of diffuse peritoneal mesothelioma is included. In this subject large effusions were present in both pleural cavities but no primary or secondary tumours were seen within the thorax. The peritoneal cavity contained fluid loculated between masses of tumourinfiltrated mesentery and omentum. The growth had spread widely on the surface of the bowel and over both surfaces of the liver, but no primary tumour could be detected in these or in the other abdominal organs. The remaining examples were thought to be primary growths of the pleura, though very extensive involvement of the peritoneum had occurred in two of them.

In nearly all instances the lung on the affected side was shrunken and encased in thick white tumour tissue which extended deeply into the interlobar fissures. The pleural space

TABle I.-Age, Sex, Duration of Illness, and Details of Occupational History in 17 Cases

\begin{tabular}{|c|c|c|c|c|c|c|c|}
\hline $\begin{array}{l}\text { Case } \\
\text { No. }\end{array}$ & Sex & Age & $\begin{array}{c}\text { Duration } \\
\text { of } \\
\text { Symptoms } \\
\text { in } \\
\text { Months }\end{array}$ & $\begin{array}{c}\text { Time Since } \\
\text { First Possible } \\
\text { Exposure } \\
\text { to Asbestos in } \\
\text { Years* }\end{array}$ & $\begin{array}{l}\text { Length } \\
\text { of } \\
\text { Exposure } \\
\text { in } \\
\text { Years* }\end{array}$ & $\begin{array}{l}\text { Interval from } \\
\text { End of Exposure } \\
\text { to Development } \\
\text { of Tumour } \\
\text { in Years }\end{array}$ & Occupation \\
\hline $\begin{array}{l}1 \\
2\end{array}$ & $\underset{\mathbf{M}}{\mathbf{F}}$ & $\begin{array}{l}82 \\
53\end{array}$ & $\begin{array}{r}18 \\
8\end{array}$ & $\begin{array}{l}(66) \\
(13)\end{array}$ & $\begin{array}{l}(55) \\
(13)\end{array}$ & $\begin{array}{r}11 \\
1\end{array}$ & $\begin{array}{l}\text { Sorter in sackware factory } \\
\text { Lagger. Also rigger, boiler-scaler, and crane-driver (demolition of } \\
\text { insulated factory plant) }\end{array}$ \\
\hline 3 & $\mathbf{F}$ & 51 & 19 & $?$ & $?$ & $?$ & $\begin{array}{l}\text { Not known to have handled asbestos (but asbestos bodies present). } \\
\text { Rubber-shoe factory. Football pools checker. Gun-drilling } 1940-45 \text {. }\end{array}$ \\
\hline $\begin{array}{l}4 \\
5 \\
6 \\
7\end{array}$ & $\begin{array}{l}M \\
M \\
M \\
M\end{array}$ & $\begin{array}{l}57 \\
57 \\
50 \\
46\end{array}$ & $\begin{array}{r}4 \\
72 \\
72 \\
10\end{array}$ & $\begin{array}{l}(40) \\
37 \\
(35) \\
(18)\end{array}$ & $\begin{array}{l}(40) \\
5 \\
(35) \\
(18)\end{array}$ & $\begin{array}{r}1 \\
32 \\
1 \\
1\end{array}$ & $\begin{array}{l}\text { Lagger } \\
\text { Lagger } \\
\text { Lagger } \\
\text { Lorry-driver for ship-repairers. Probable environmental exposure. } \\
\text { Asbestos bodies present. }\end{array}$ \\
\hline $\begin{array}{r}8 \\
9 \\
10 \\
11 \\
12 \\
13 \\
14\end{array}$ & $\begin{array}{c}\mathbf{M} \\
\mathbf{M} \\
\mathbf{M} \\
\mathbf{F} \\
\mathbf{M} \\
\mathbf{F} \\
\mathbf{F}\end{array}$ & $\begin{array}{c}71 \\
60 \\
58 \\
62 \\
50 \\
56 \\
\text { Alive } 53\end{array}$ & $\begin{array}{r}5 \\
5 \\
12 \\
23 \\
24 \\
15 \\
15\end{array}$ & $\begin{array}{l}(55) \\
(45) \\
43 \\
45 \\
35 \\
42 \\
36\end{array}$ & $\begin{array}{c}(53) \\
(45) \\
43 \\
5 \\
35 \\
20 \\
13\end{array}$ & $\begin{array}{r}2 \\
1 \\
1 \\
40 \\
1 \\
22 \\
23\end{array}$ & $\begin{array}{l}\text { Sheet-metal worker in ship-repairers' yard } \\
\text { Lagger (ship-building) } \\
\text { Asbestos factory (foreman) } \\
\text { Asbestos factory (card-room operative) } \\
\text { Boiler-maker (ship-building) } \\
\text { Sorter in sackware factory } \\
\text { Office worker for concrete manufacturers-users of asbestos cement }\end{array}$ \\
\hline
\end{tabular}

Cases with no Clear Evidence of Exposure to Asbestos

\begin{tabular}{|c|c|c|c|c|c|c|c|c|}
\hline & & \multicolumn{7}{|c|}{ Cases with no Clear Evidence of Exposure to Asbestos } \\
\hline $\begin{array}{l}15 \\
16\end{array}$ & $\begin{array}{l}M \\
M\end{array}$ & $\begin{array}{l}82 \\
65\end{array}$ & $\begin{array}{l}2 \\
6\end{array}$ & 二 & 二 & 二 & $\begin{array}{l}\text { Boiler-maker (ship-building) } \\
\text { Apprenticed to ship-repairers and ship-fitters for } 7 \text { years. }\end{array}$ & Later store- \\
\hline 17 & $\mathbf{M}$ & 61 & 38 & - & - & - & $\begin{array}{l}\text { man at corporation water department } \\
\text { Dock railway porter }\end{array}$ & \\
\hline
\end{tabular}

- Figures in parentheses are approximate.

TABLe II.-Main Pathological Findings at Post-mortem Examination in 12 Cases

\begin{tabular}{|c|c|c|c|c|c|c|}
\hline $\begin{array}{l}\text { Case } \\
\text { No. }\end{array}$ & $\begin{array}{l}\text { Main Tumour } \\
\text { Site }\end{array}$ & Lymph-node Deposits & $\begin{array}{c}\text { Distant } \\
\text { Metastases }\end{array}$ & $\begin{array}{c}\text { Involvement of } \\
\text { Other Serous Cavities }\end{array}$ & $\begin{array}{c}\text { Predominant Histological } \\
\text { Tumour Type }\end{array}$ & $\begin{array}{l}\text { Asbestos Bodies } \\
\text { in Lung Tissues }\end{array}$ \\
\hline 1 & Right pleura & Axillary, internal mammary & - & Pericardium. & Undifferentiated growth & + \\
\hline $\begin{array}{l}2 \\
3 \\
4\end{array}$ & $\begin{array}{l}\text { Left pleura } \\
\text { Left pleura } \\
\text { Right and left } \\
\text { pleura }\end{array}$ & $\begin{array}{l}\text { Axillary, cervical, mediastinal } \\
\text { Mediastinal } \\
\text { None }\end{array}$ & $\begin{array}{l}\text { Liver } \\
\text { - }\end{array}$ & $\begin{array}{l}\text { Peritoneum-liver surtace } \\
\text { Pericardium } \\
\text { Pericardium } \\
\text { Both pleural cavities. } \\
\text { Peritoneum-old gastrectomy } \\
\text { scar, inguinal-hernia sac, sur- } \\
\text { face of pancreas }\end{array}$ & $\begin{array}{l}\text { Undifferentiated growth } \\
\text { Mixed } \\
\text { Mixed }\end{array}$ & $\begin{array}{l}+ \\
+ \\
+\end{array}$ \\
\hline 5 & $\begin{array}{l}\text { Right and left } \\
\text { pleura }\end{array}$ & Mediastinal & 一 & Both pleural cavities & Mixed & + \\
\hline 6 & Left pleura & None & 一 & Right pleural cavity & Sarcomatous & + \\
\hline 7 & Left pleura & $\begin{array}{l}\text { Axillary, mediastinal, } \\
\text { abdominal }\end{array}$ & - & $\begin{array}{l}\text { Peritoneum-mesenteric deposits } \\
\text { Pericardium. }\end{array}$ & Mixed & + \\
\hline $\begin{array}{r}8 \\
9 \\
10\end{array}$ & $\begin{array}{l}\text { Right pleura } \\
\text { Peritoneum } \\
\text { Left pleura }\end{array}$ & $\begin{array}{l}\text { None } \\
\text { None }\end{array}$ & 二 & $\begin{array}{l}\text { None } \\
\text { None } \\
\text { Pericardium. } \\
\text { Peritoneum-surface of liver, } \\
\text { surface of adrenal }\end{array}$ & $\begin{array}{l}\text { Mixed } \\
\text { Papillary } \\
\text { No histological material } \\
\quad \text { available }\end{array}$ & $\begin{array}{l}\text { Dubious } \\
\text { No lung tissue } \\
\text { No lung tissue }\end{array}$ \\
\hline $\begin{array}{l}15 \\
17\end{array}$ & $\begin{array}{l}\text { Right pleura } \\
\text { Right pleura }\end{array}$ & $\begin{array}{l}\text { None } \\
\text { None }\end{array}$ & $\overline{-}$ & $\begin{array}{l}\text { None } \\
\text { Both pleural cavities. } \\
\text { Pericardium. } \\
\text { Peritoneum-covering all organs }\end{array}$ & $\begin{array}{l}\text { Sarcomatous } \\
\text { Mixed }\end{array}$ & $\begin{array}{l}\text { No lung tissue } \\
\text { Small fragment only of } \\
\text { lung }\end{array}$ \\
\hline
\end{tabular}


was often obliterated so that no distinction could be made between the visceral and parietal layers. In other examples loculated collections of fluid were present, and in one instance the pleural surfaces were separated by a large effusion though both layers were completely replaced by growth measuring up to $2 \mathrm{~cm}$. in thickness. Thickest tumour was generally seen on the surface of th: diapiragm and over the lung bases.

Infiltration of intercostal tissues and mediastinal structures was noted in all cases, with a tendency to penetrate the chest wall at the site of previous thoracotomy. Bilateral pleural involvement was unusual, being noted on only three occasions, but there were several examples of tumour extension to other serous cavities. The pericardium was directly invaded in six instances, with extension of tumour on to the surface of the heart in three of these. Peritoneal deposits were present in six examples, four of which showed pericardial involvement as well.

Only one blood-borne metastasis was encountered. This was an isolated small nodule of tumour situated deeply within the substance of the liver. Lymphatic spread was recorded much more frequently, axillary or mediastinal lymph-node deposits being present in half the cases. One patient showed extensive thoracic and abdominal lymph-node involvement together with prominent intrapulmonary lymphangitic spread of tumour.

All reports state that no primary carcinoma could be found in the body, the organs examined being listed in most of them. Two of the post-mortem examinations were carried out personally. No neoplasms other than the primary growths in the pleura were found after careful dissection of the bronchial tree and thorough examination of all organs, including breasts, thyroid, prostate, and testes.

\section{Histological Appearances of Tumours}

Diffuse mesotheliomas of the pleura and peritoneum are comparatively rare tumours and their histological diagnosis has been the subject of controversy for many years, Robertson (1924) and Willis (1960) denying their existence as a separate entity. Difficulty in diagnosis arises from the variation in structure shown by these tumours and from a similarity in many instances to secondary adeno-carcinoma or to fibrosarcoma. Detailed descriptions of the microscopical features have been given by Klemperer and Rabin (1931), Carnpbell (1950), Godwin (1957), and McCaughey (1958). All these quthors emphasize the presence of a mixed structural pattern and attribute this to the dual potentiality of mesothelium from which both endothelial and mesenchymatous elements may be formed. Characteristically, areas of endothelial proliferation into papillary structures and into tumour-lined clefts within 2 fibrous stroma merge or mix with areas of fibroblastic activity, often of sarcomatous appearance. McCaughey divides is 11 examples into those of mainly epithelial pattern, those if fibrous structure, mixed tumours, and anaplastic spindle-cei growths.

A mixed pattern was clearly seen in 11 of the 16 tumours examined in this series. Two others were predominantly of sarcomatous appearance, one was predominantly papillary, and two were poorly differentiated growths composed of sheets of malignant cells with several multinucleated giant forms. None of the tumours showing a predominance of one structura! pattern was uniformly of one cell type, and in every example some areas were present in which other features of mesothelioma could be distinguished. It can therefore be said that a mixed pattern was present to some degree in all the examples studied. To demonstrate this it was necessary in a few cases to study blocks of tissue from several different areas of tumour. The only metastasis encountered was entirely of fibrosarcomatous structure. The primary growth in the pleura was of mixed type showing papillary and tubular endothelial structures mixed with areas of fibrosarcoma. Typical examples of tumour-lined clefts and papillary growth are shown in Figs. 1, 2, and 3 (Special Plate).

Meyer and Chaffee (1940) showed the presence of hyaluronic acid in the serous effusions of cases of mesothelioma. Its presence in the endothelial component of tumour tissue provides an additional diagnostic feature of mesothelioma and has been demonstrated histochemically by Wagner et al. (1962). In all 16 cases which they examined secretion was present which stained metachromatically with azure " A" and which gave a positive reaction with alcian blue and with Hale's colloidal-iron nuthod. These reactions were abolished or much reduced in all instances after treatment of the tissues with testicular hyaluronidase, in marked contrast to the behaviour of mucin in secreting adenocarcinomas where the colours persist. In addition there was consistent failure of the endothelial components to stain with the periodic-acid-Schiff (P.A.S.) reagent, whereas mucin was demonstrated by this method in all examples of adenocarcinoma which they examined. Similar results were reported by Winslow and Taylor (1960) in a series of 12 cases of malignant peritoneal mesothelioma.

Similar methods were applied to all available tissues in this series, mucicarmine being used in preference to P.A.S. for the demonstration of mucin secretion. Positive reactions were obtained with alcian blue and with Hale's colloidal iron in every instance, and in each one a marked reduction in intensity of colour followed treatment with hyaluronidase. In only two of the specimens was the colour entirely abolished after 18 hours' incubation, but persistence of strong colour was demonstrated consistently in control examples of normal mucinsecreting tissues and of mucin-secreting adenocarcinomas. Mucicarmine failed to give a reaction in all but one of the examples, and this gave only scanty and faint staining which was abolished by treatment with hyaluronidase. Similar reactions in the stromal elements were observed in several tumours, but these were regarded as non-specific, as hyaluronic acid is known to be produced by rapidly growing connective tissues in other situations.

\section{Asbestos Bodies in Lung Tissue}

Very little lung tissue had been preserved for examination, most of the thoracotomy specimens and some of the necropsy material consisting only of tumour tissue. Blocks containing lung tissue were available in 10 cases and asbestos bodies were identified in seven of these. Asbestos bodies are formed by the encrustation of inhaled asbestos fibres by an iron-protein complex. They appear as beaded structures of golden-brown colour in routine haematoxylin-and-eosin preparations and give an intensely blue colour characteristic of iron in Perls's reaction. Fxamples are shown in Figs. 4 and 5 (Special Plate). Asbestos bodies were numerous and easily detected in the lungs of two patients but were scanty in the rest of the material, prolonged search being necessary to find them. Only fragments of lung tissue attached to pleural tumour were available for examination in the three negative cases. In no instance were asbestos bodies seen within tumour tissue. Some degree of fibrosis was observed in all samples of lung tissue, but its extent was minimal, being confined to the walls of respiratory bronchioles. This degree of fibrous reaction was thought to be consistent with the absence of clinical features of pulmonary asbestosis in these patients.

\section{Illustrative Case Histories}

The following short case histories have been selected to illustrate points of environmental, clinical, and pathological interest. 


\section{Case 1. Female. 82 years. Died 1963}

Occupational history in this case was given by the patient's daughter, who had worked for several years in the same factory as her mother. The patient had been employed from 16 to 71 years of age by a firm of sackware manufacturers as a sorter of used sacking. Sacks were received which had contained a great variety of materials and which had come from all over the world. Asbestos sacks were often handled and were said to be exceptionally dusty.

The patient was admitted to hospital suffering from bronchopneumonia and fractured neck of femur, and died three weeks later. She had been losing weight for 18 months and had complained of increasing breathlessness for over two years.

At necropsy the right lung was encased in thick white tumour tissue which completely obliterated the pleural space. Growth had infiltrated intercostal tissues, mediastinal structures, and the pericardium. A nodule of tumour was present on the surface of the liver, where growth had penetrated the diaphragm, and there were deposits of tumour in axillary and internal mammary lymph nodes on the right side. The breasts, lungs, ovaries, and gastro-intestinal tract were carefully examined, but no carcinoma was found in these or in any other organ in the body. Asbestos bodies were seen in smears made from the cut surfaces of the lungs and in histological sections of lung tissue.

\section{Case 6. Male. 50 years. Died 1963}

This patient had worked for most of his life as a lagger of steam pipes and boilers and had handled asbestos regularly. A few months before he died he had changed to lighter work as the controller of a machine for making asbestos net.

He began to have intermittent chest pain in 1957. By 1959 he had become breathless on exertion, and in December 1961 he was admitted to hospital because of severe dyspnoea. A large pleural effusion was present and aspiration of fluid was carried out through the sixth left intercostal space. Three months later a subcutaneous tumour had formed at the site of aspiration. This mass increased slowly in size over the next 19 months but the patient remained at work. He then began to lose weight, became increasingly breathless, and suffered persistent pain in the chest and in the left shoulder. He died a few days after readmission to hospital in October 1963.

At necropsy a mass was present in subcutaneous tissues over the fifth and sixth ribs on the left side. This was seen to be an extension of tumour from the parietal pleura, which was everywhere infiltrated by malignant growth. A large pleural effusion was present and aspiration was carried out, together with needle biopsy of the pleura. Tumour had infiltrated the mediastinum, encasing part of the aorta. Fluid was present in the peritoneal cavity and there were several small tumour nodules scattered over the mesenteries. No other growths were found. Asbestos bodies were present in profusion in the lungs.

\section{Case 7. Male. 46 years. Died 1963}

In this case there was no history of direct contact with asbestos. From 1945 onwards the patient had worked as a lorry-driver for a firm of ship repairers and fitters. His loads consisted mainly of machine components, but he had carried powdered asbestos on a number of occasions. This material had always been contained in sealed bags, and he denied handling it himself, all loading and unloading being carried out by other workmen. He did not think that he had been exposed to asbestos dust inside the factory or at the docks, which he frequently visited.

When admitted to hospital in July 1963 he had been breathless for six months and had complained of pain in the chest for two weeks. A large left pleural effusion was present. Bronchoscopy showed no abnormality. At thoracotomy tumour nodules were seen on both pleural surfaces. These were thickest over the lung base and on the surface of the diaphragm. Fluid reaccumulated postoperatively and continued to ooze through the thoracotomy incision. He remained in hospital for eight weeks and was later readmitted for short periods for pleural aspirations to relieve breathlessness. He appeared more ill at each attendance, losing weight and developing ascites. He was finally admitted in December 1963, and died three weeks later.

At necropsy the left lung was encased in thick tumour tissue which completely obliterated the pleural space. Tumour had pene- trated the chest wall to form a subcutaneous mass deep to the old thoracotomy scar and there were several skin nodules in the vicinity of the scar. The pericardium had been directly invaded and the thoracic aorta was encased by tumour. Within the abdomen there was massive replacement of the mesenteries and the omentum. Growth had also filled the pelvic cavity, encasing the bladder, the ureters, and the rectum. No primary growth could be found in these or in any other organ in the body. Tumour deposits were present in hepatic, pancreatic, para-aortic, mediastinal, and axillary lymph nodes. Asbestos bodies were present in smears made from the cut surfaces of the lungs and in sections of lung tissue.

\section{Case 12. Male. 50 years. Died 1955}

This man had been a boiler-maker and sheet-metal worker and was employed all his life by a firm of ship repairers and fitters. $\mathrm{He}$ was engaged in the construction of many insulated "boilers" and was known to have handled asbestos. In addition he was often exposed to asbestos dust during the mixing of materials for the "magnesia" process. This method is used for the insulation of large surfaces. Powdered asbestos and magnesium carbonate are mixed together and made into a paste with water, the moist material being applied to the surface requiring insulation.

He was admitted to hospital in May 1954 because of increasing breathlessness over a period of six months. A large right pleural effusion was aspirated several times, but fluid continued to accumulate. He was transferred to the thoracic surgery unit in July 1954 No abnormality was seen at bronchoscopy. Exploratory thoracotomy showed irregular patches of thickened pleura, mainly in the parietai layer and particularly over the surface of the diaphragm. Others were present on the mediastinal surfaces. He remained in hospital for a further six weeks, and during this time 16 separate aspirations of fluid were made. After discharge home, fluid continued to accumulate and to ooze persistently through the operation scar. He was in constant pain, and his wife administered a total of $500 \mathrm{~g}$. (32.4 kg.) morphine under medical guidance over the next 14 months. He died in November 1955. Post-mortem examination was not carried out. The specimens taken at thoracotomy consisted entirely of tumour and there was no lung tissue available for examination.

\section{Discussion}

The occurrence of lung cancer in cases of asbestosis has been frequently recorded since 1935, when correlation between the two conditions was suggested by Lynch and Smith (1935). Gloyne (1951) found lung cancer in $14.1 \%$ of 121 deaths associated with asbestosis, and Merewether (1954) found 55 lung cancers in a study of 344 cases of asbestosis (16\%).

An association between mesothelioma and asbestosis was first described by Wedler (1943) in Germany. Keal (1960) studied the records of 42 cases of asbestosis at the London Hospital. Out of 23 women, four had died of lung cancer, one had died of ovarian carcinoma, and eight had diffuse peritoneal growths of uncertain origin. Out of $19 \mathrm{men}, 10 \mathrm{had}$ died of lung cancer and one from probable diffuse mesothelioma of the peritoneum. König (1960) described nine lung tumours, four pleural mesotheliomas, and three peritoneal mesotheliomas in subjects exposed to asbestos.

Conversely, exposure to asbestos had occurred in all but one of the 33 cases of diffuse pleural mesothelioma studied by Wagner et al. (1960) and in all but two of the larger series of 78 cases of pleural and peritoneal mesothelioma described by Wagner (1962). Since then McCaughey et al. (1962) have found asbestos bodies in the lungs in 13 out of 15 cases of diffuse pleural mesothelioma. This very striking incidence in asbestos workers is confirmed by the results of the present investigation, and it is concluded that exposure to asbestos is a major factor and possibly an essential one in the causation of diffuse mesothelioma.

No attempt has been made to identify the type of asbestos used by these patients. All the South African cases had been exposed to crocidolite. Chrysotile and amosite are also mined in South Africa, but none of the patients had worked exclusively 
with these fibres. On the other hand, Cartier (1952) mentioned two cases of diffuse mesothelioma from a Canadian chrysotile mine.

It is clear that evidence of exposure to asbestos may assist in the diagnostic of diffuse mesothelioma and that a careful occupational history should be obtained in cases of prolonged chest pain or recurrent pleural effusion of obscure origin. The presence of hyaluronic acid in serous effusions is said to provide confirmatory evidence, and a simple screening test is available for the detection of this substance (Wagner et al. (1962). No pleural or peritoneal fluids have been available for examination in this series.

\section{Summary}

Seventeen cases of diffuse mesothelioma occurring in the $M$ irseyside area were investigated and evidence was sought of exposure to asbestos dust.

An account is given of the clinical features of diffuse mesoth.elioma, and in 12 cases the pathological findings at postmortem examination are described.

Difficulties of histological diagnosis are discussed and the histological appearance of the tumours described.

Exposure to asbestos had occurred in $14(82 \%)$ of the 17 cases examined, and asbestos bodies were seen in seven out of 10 specimens of lung tissue examined.

It is concluded that exposure to asbestos is a major factor in the causation of diffuse mesothelioma.

ADDENDUM.-Since this paper was submitted two further papers (Enticknap and Smither, 1964 ; Hourihane, 1964) have been published, both dealing with the subject of mesothelioma and asbestos.
I am grateful to the surgeons of the Liverpool Thoracic Surgery Unit for permission to study the medical records of cases under their care, and to Dr. Edith M. McConnell for searching the files of the Liverpool Cancer Control Organization. I am indebted to Dr. H. McClean, Dr. Rachel M. Rawcliffe, Dr. P. J. Taylor, Dr. H. E. Vickers, and Dr. A. S. Woodcock for making available post-mortem records and for sending blocks of tissue from their cases. My thanks are due to Dr. F. Whitwell and Dr. J. A. Campbell for their constant encouragement, and to Dr. J. C. Wagner, of the M.R.C. Pneumoconiosis Research Unit, who first suggested the investigation and who has helped me at many stages. The work could not have been carried out without the enthusiastic assistance of $\mathrm{Mr}$. A. Robertson, who devoted much time to the preparation of the histological material.

\section{REFERENCES}

Campbell, W. N. (1950). Amer. F. Path., 26, 473.

Cartier, P. (1952). Arch. industr. Hyg., 5, 262

Doll, R. (1955). Brit. F. industr. Med., 12, 81

Enticknap, J. B., and Smither, W. J. (1964). Ibid., 21, 20.

Gloyne, S. R. (1951). Lancet, 1, 810.

Godwin, M. C. (1957). Cancer (Philad.), 10, 298.

Hourihane, D. O'B. (1964). Thorax, 19, 268

Keal, E. E. (1960). Lancet, 2, 1211

Klemperer, P., and Rabin, C. B. (1931). Arch. Path., 11, 385.

König, J. (1960). Arch. Gewerbepath. Gewerbehyg., 18, 159.

Lynch, K. M., and Smith, W. A. (1935). Amer. Ұ. Cancer, 24, 56.

McCaughey, W. T. E. (1958). F. Path. Bact., 76, 517.

McCaughey, W. T. E. Wade, O. L., and Elmes, P. C. (1962). Brit. med. 7., 2, 1397

Merewether, E. R. A. (1954). Annual Report, Chief Inspector of Factories. H.M.S.O., London.

Meyer, K., and Chaffee, E. (1940). f. biol. Chem., 133, 83.

Robertson, H. E. (1924). F. Cancer Res., 8, 317.

Wagner, J. C. (1962). "The Pathology of Asbestosis in South Africa." A thesis accepted by the University of the Witwatersrand for the Degree of Doctor of Medicine.

- Munday, D. E., and Harington, J. S. (1962). 7. Path. Bact., 84, 73.

- Sleggs, C. A., and Marchand, P. (1960). Brit. f. industr. Med., 17,260

Wedler, H. W. (1943). Dtsch. med. Wschr., 69, 575.

Willis, R. A. (1960). Pathology of Tumours, 3rd ed. Butterworth, London.

Winslow, D. J., and Taylor, H. B. (1960). Cancer (Philad.), 13, 127.

\title{
Hyperparathyroidism and Cancer
}

\author{
C. E. DENT,* M.D., F.R.S. ; L. C. A. WATSON,* M.B., M.R.A.C.P.
}

[With Special Plate]

Brit. med. F., 1964, 2, 218-221

The cause of hypercalcaemia in a particular patient can usually be established with great certainty. This has been emphasized in several reviews, including those of Albright and Reifenstein (1948), Thomas et al. (1959), and David et al. (1962), and such has been our experience in this unit.

A difficult problem still arises in the differential diagnosis of hypercalcaemia when more than one of the known causes is present in the one patient, a situation which seems to occur more often than it should. Case reports of these associations include hyperparathyroidism and thyrotoxicosis (Bortz et al., 1961 ; Jackson et al., 1961), hyperparathyroidism and sarcoidosis (Burr et al., 1959), hyperparathyroidism and Paget's disease (Kohn and Myerson, 1961), and hyperparathyroidism and cancer (Hellström and Ivemark, 1962).

We are reporting our findings from a severely hypercalcaemic patient, who proved to have both a primary carcinoma of the cervix uteri and primary hyperparathyroidism due to parathyroid adenoma.

* Member of the Medical Unit, University College Hospital and Medical School, London.

\section{Case Report}

A married woman aged 37 was admitted to University College Hospital in August 1962. She was the mother of six children, whose ages ranged from 17 years to 3 months. She had few complaints. She had been a little more tired than usual since the beginning of her sixth pregnancy and perhaps a little thirsty. When six months pregnant she slipped and fell from a bus and was admitted to Redhill Hospital because of abdominal pain, which quickly settled down. She soon felt very well but was found to be anaemic, with a haemoglobin of about $50 \%$. She was given two blood transfusions, each of 2 pints $(1,140 \mathrm{ml}$.) and discharged. Three months later she came into labour, which was rather prolonged, lasting about 25 hours and terminating with the aid of vacuum extraction. This was unusual for her, as she had previously had quick and easy labours at home.

During the puerperium investigations revealed that the plasma calcium level was raised, as was the plasma alkaline phosphatase, while the plasma phosphorus level was abnormally low. At this stage the patient insisted that she was free of symptoms and that she should be allowed to leave hospital in order to look after her family. In August she returned for a post-natal follow-up examination, when the S.H.O. (Mr. A. R. F. Williams) thought that the 